\title{
Management of Anoestrus Murrah Buffaloes Using Two Different Hormonal Approaches
}

\author{
Meenakshi Virmani*, R.K. Malik, Kennady Vijayalakshmy, \\ Pardeep Singh and S.K. Chhikara
}

Department of Veterinary Physiology and Biochemistry, College of Veterinary Sciences, Lala

Lajpat Rai University of Veterinary and Animal Sciences, Hisar, Haryana 125004, India

*Corresponding author

\begin{tabular}{|c|}
\hline Keywords \\
\hline $\begin{array}{l}\text { Anoestrus, Buffalo, } \\
\text { CIDR, Cyclicity, } \\
\text { Heat stress, } \\
\text { Hormone }\end{array}$ \\
\hline Article Info \\
\hline $\begin{array}{l}\text { Accepted: } \\
\text { 26 December } 2017 \\
\text { Available Online: } \\
\text { 10 January } 2018\end{array}$ \\
\hline
\end{tabular}

A B S T R A C T

A study was carried out to induce the cyclicity in anoestrus Murrah buffaloes with different hormonal preparations and biochemical changes in blood occurring during anoestrus were also studied. The present investigation was conducted during summer season (April-May) and the buffaloes were randomly divided into two groups of 12 animals each, viz., Group I (n=12; CIDR + PMSG 500 I.U. + hCG 1500 I.U.) animals treated with CIDR protocol and Group II ( $\mathrm{n}=12$; Hydroxyprogesterone caproate $500 \mathrm{mg}+$ Estradiol valerate 5mg + PMSG 500 I.U) animals treated with Progesterone and Estradiol (P and E) combination protocol. Murrah buffaloes were maintained in the shed and were provided with ad libitum feed and water. The results of present investigation revealed that CIDR in combination with PMSG + hCG gave better results in terms of induction of cyclicity and conception as compared to the other treatment group. A significant decline in total protein, albumin and SGPT values were recorded in anoestrus animals as compared to normal cyclic animals. The outcome from this experiment provides beneficial information to induce the cyclicity in anoestrus Murrah buffaloes using different hormonal preparations which also helps in maintaining production strategies of animals during extreme summer season in transgangetic plain region.

\section{Introduction}

Buffalo is a multipurpose species contributing towards milk, meat production and draft purpose and they are originated in Mediterranean and transgangetic plain region of North-Western India (Zicarelli, 1994 and Barile, 2005). The population of buffalo (Bubalus bubalis) around the world is predicted crudely 177 million and almost 97\% are tended in several Asian countries (FAOSTAT, 2007). The buffalo can be allocated in two subspecies i.e. swamp and riverine buffaloes; both have abilities like adapting to harsh environmental conditions, maintenance on poor quality roughages and develops resistance to various tropical diseases. Proficient feed conversion efficiency and squat maintenance necessities of buffalo also ingratiate it to the various poor farmers 
(Zicarelli, 1994). Alike other productive farm animals, production of buffaloes is also chiefly reliant on the efficacious reproduction.

The buffaloes are termed as lethargic breeder as the reproductive competence of buffalo is adversely affected by firm limitations such as delayed maturity, poor oestrous signs expression primarily during summer, irregularity in oestrous cycle, silent heat, poor conception rate, seasonal variation in breeding, early embryonic mortality and sustained inter-calving interval (Madan, 1990). The above mentioned factors either by direct or indirect means may affect the reproductive competence of buffaloes by means of modulating their sex hormones.

There is plentiful evidence that reproduction of buffalo in subtropical and tropical areas of the world is deliberated as short day breeder and its efficiency in reproductive activities is momentously and unfavourably influenced by bio meteorological factors i.e., length of the day, relative humidity, ambient temperature etc. (Singh et al., 2000; Ribeiro et al., 2003). Conversely, buffaloes which are maintained in equatorial zone display oestrous cycle throughout the year, whereas adequate nutrition has to be provided in order to retain the reproductive proficiency. Also they exhibit seasonally polyoestrous character when they move with an expanse from the equator credited to the environmental factors and photoperiod (Zicarelli, 1994; Baruselli, 2001). Indian buffaloes are polyestrous and show a discrete seasonal variant in exhibition of oestrus, calving rate and conception rate, but improved reproductive adeptness during winter months. (Madan, 1998; Tailor et al., 1990).

Till today, it is uncertain whether poor reproductive efficiency in case of buffaloes during summer or seasonal variations is accredited to genetic characteristics of buffalo or ecological factors or nutrition. Though, various evidences suggest a strong impact of bio meteorological factors on the endocrine system of buffaloes (i.e., day length, relative humidity, ambient temperature and rain fall (Shah, 1988). The fraction of buffaloes displaying oestrus during the period of diminutive day length was considerably greater than during the period of long day length (74\% versus $26 \%$, respectively) (Tailor et al., 1990). The hostile effect of diverse bio meteorological factors on meagre reproductive efficiency in buffaloes during summer months needs to be explored with further experiments via looking at the effect of nutrition, high ambient temperature, photoperiod, humidity etc. independently or in grouping during different seasons (Singh and Nanda, 1993). The postulate of the present study is that summer stress affects livestock production by means of increasing the incidence of anoestrus in postpartum Murrah buffaloes in Trans Gangetic plain region. With this objective, the current trial has been commenced with the prime objective to induce the cyclicity in anoestrus Murrah buffaloes using various hormonal preparations.

\section{Materials and Methods}

\section{Location and climate}

The experimental trial was carried out during the month of July to September at the Buffalo Farm, Department of Livestock Production and Management, Lala Lajpat Rai University of Veterinary and Animal Sciences, Hisar (Haryana), which is situated in Trans-Gangetic plain region of India at longitude $75^{\circ} 43^{\prime}$ $02.84^{\prime \prime} \mathrm{E}$ and the latitude of $29^{\circ} 09^{\prime} 14.28^{\prime \prime} \mathrm{N}$ and at altitude of $234 \mathrm{~m}$ above mean sea level. The average annual maximum and minimum ambient temperature ranges between 6 and 46 ${ }^{\circ} \mathrm{C}$. The mean annual relative humidity ranges between $20 \%$ and $85 \%$. The annual rainfall in this area ranges from 350 to $455 \mathrm{~mm}$ with 
an intermittent distribution throughout the year.

\section{Animals}

24 adult Murrah buffaloes that were acyclic for more than 200 days after calving (based on the farm records) were included in the present study. The animals were approximately of $2^{\text {nd }}$ $-3^{\text {rd }}$ lactation and nutritional health status with the history of postpartum anoestrus. They were housed in well-ventilated sheds under proper hygienic conditions. Buffaloes in the shed were exposed to a temperature range of $35-45{ }^{\circ} \mathrm{C}$ and relative humidity (RH) of around 15-20\%. Animals were provided with adlibitum feed and water during experimental procedure. The animals were provided with good quality drinking water. Optimum health score conditions and managemental care was confirmed in each animal as per the BCSscore card (Balakrishnan et al. 1997). Buffalo cows were examined by vision and palpation to indicate body condition score in 1 to 5 scale and were classified as 1.0-1.5 poor (emaciated), 2.0-2.5 Moderate (Thin), 3.0-3.5 Good (Average), 4.0- 4.5 Fat (Heavy condition) and 5.0 Grossly fat. The body condition score for each of the experimental animal was above 2.5 .

\section{Experimental procedure}

All the anoestrus Murrah buffaloes included in the present study were confirmed for their reproductive status by trans-rectal examination (palpation and ultrasonography) of ovaries on two occasions at eleven days interval to find out presence or absence of corpus luteum (CL) or any other structure and were randomly divided into two groups. In Group I animals $(\mathrm{n}=12)$, CIDR (Eazi-breed CIDR ${ }^{\mathrm{TM}}$, Inter Ag, Hamilton, New Zealand) was inserted intravaginally (day 0) and subsequently removed on day 8. PMSG (Folligon ${ }^{\circledR}$, Intervet International, The Netherlands) of about 500
I.U. was administered intramuscularly on day 7 (one day prior to CIDR withdrawal) and an injection of hCG (Chorulon $^{\circledR}$, Intervet International, The Netherlands) of 1500 I.U. was administered intramuscularly at the time of artificial insemination (A.I.) with frozen thawed semen. Group II animals were treated with $\mathrm{P}$ and $\mathrm{E}$ combination protocol in which animals were administered subcutaneous injection of Hydroxyprogesterone caproate $500 \mathrm{mg}$ (Duraprogen $2 \mathrm{ml}$ ) and $5 \mathrm{mg}$ of Estradiol valerate (Progynon $\operatorname{depot}^{\circledR}$, German Remedies) was administered intramuscularly followed by intramuscular Injection of 500 I.U. of PMSG (Folligon ${ }^{\circledR}$, Intervet International, The Netherlands) on day 8 . Oestrus was detected by parading a vasectomized teaser buffalo bull twice, once in the morning and once in the evening. Artificial insemination was done at the appropriate time after detection of oestrus. Pregnancy diagnosis was performed through rectal examination after 60-90 days of A.I. when the animals did not return to oestrus after artificial insemination. Oestrus response was observed as percentage of females showing oestrous out of total animals treated. First service conception rate was calculated as percentage of animals conceived to first insemination at induced oestrus in each group. Comparative study of both the treatment regimens was carried out by comparing their efficacy for oestrus induction and successful conception. Blood samples were collected from jugular vein of Murrah buffaloes at weekly intervals to study the effects of anoestrus on the blood biochemical and enzymatic parameters.

\section{Blood collection and plasma separation}

All the hormonally treated/untreated true anoestrus and normal cyclic cows were studied for their reproductive status, biochemical and enzymatic profile. For this, jugular blood samples were collected in 
heparinized vacutainers (BR Vacutainer Precision Glide, Becton Dickinson India Pvt Ltd.) 4 times from true anoestrus animals, i.e., on day 0 - just before treatment (on diagnosis), on day 7 - at the time of PMSG administration, on day 9 - induced oestrus/FTAI (FTAI done twice 24hourapart, i.e., on day 9 and 10 after initiation of treatment) and on day 21 post-AI. Blood sampling for control groups was done on the day of spontaneous oestrus if any, and on day 21 post-AI. The samples were centrifuged at $3000 \mathrm{rpm}$ for $15 \mathrm{~min}$ and plasma separated out was stored deep frozen at $-20^{\circ} \mathrm{C}$ until analysed.

\section{Parameters studied}

The biochemical parameters, viz., plasma urea, plasma creatinine, total plasma protein, total plasma cholesterol, plasma calcium, plasma albumin and enzymatic parameters such as Aspartate amino transaminase, alanine transferase and alkaline phosphatise were estimated using fully automated random access clinical chemistry analyser. The data on biochemical and enzymatic constituents was examined statistically and done with analysis of variance (Snedecor and Cochran 1994).

\section{Results and Discussion}

\section{Oestrus induction and conception rate}

All the Murrah buffaloes (100\%) in group I and II exhibited induced oestrus within 48-96 hour after treatment as recorded by parading a teaser bull. All the animals showed noticeable heat indications such as vulvar oedema, vulvar mucus membrane congestion, tonicity of uterine horn and opening of os-cervix. The greater oestrus response in animals treated with CIDR protocol may potentially be due to
PMSG supplementation along with CIDR. PMSG helps to induce the behavioural oestrus by means of enhancing ovarian stimulation (Singh et al. 2004). In the current study, animals were inseminated using cryopreserved semen. In group I, 66.66\% cows conceived at first service. In contrast, the conception rate in group II cows was recorded to be $33.33 \%$ at first service. The conception rates acquired at induced oestrus in Murrah Buffaloes by means of these two protocols were $66.66 \%$ and $33.33 \%$ respectively, with corresponding overall pregnancy rates of three cycles as $83.33 \%$ and $50.00 \%$. However, higher conception rate was recorded by the administration of progesterone based CIDR protocol as compared to the Ovsynch protocol.

\section{Biochemical parameters}

Table 2 describes the effects of oestrus induction on various blood biochemical parameters. There was no significant variation in the values of other biochemical parameters in anoestrus animals as compared to normal cyclic animals. However, a significant decline in total protein and albumin in anoestrus animals of group I and II as compared to control animals.

\section{Enzymatic parameters}

Table 3 describes mean values of various blood enzymatic parameters in anoestrus and normal cyclic animals. The anoestrus animals of group I $(55.883 \pm 2.023)$ and group II $(50.950 \pm 3.004)$ showed a significant decline in the value of ALT as compared to control (cyclic) animals (63.550 \pm 1.507$)$. Other enzymes viz., aspartate aminotransferase and alkaline phosphatase didn't show any significant variation in anoestrus and cyclic animals. 
Table.1 Effects of hormonal protocols on oestrus induction response and conception rate in anoestrus Murrah Buffaloes

\begin{tabular}{|c|c|c|c|c|c|}
$\begin{array}{c}\text { Treatment } \\
\text { groups }\end{array}$ & $\begin{array}{c}\text { No. of } \\
\text { Animals }\end{array}$ & $\begin{array}{c}\text { Oestrus } \\
\text { induction } \\
\text { response } \\
(\%)\end{array}$ & $\begin{array}{c}\text { At } \\
\text { Induced/First } \\
\text { Oestrus }\end{array}$ & $\begin{array}{c}\text { Conception Rate (\%) } \\
\text { Ot Second }\end{array}$ & Overall \\
\hline Group I & 12 & 100 & $\begin{array}{c}66.66 \% \\
(8 / 12)\end{array}$ & $\begin{array}{c}16.66 \% \\
(2 / 12)\end{array}$ & $\begin{array}{c}83.33 \% \\
(10 / 12)\end{array}$ \\
\hline Group II & 12 & 100 & $33.33 \%$ & $\begin{array}{c}16.66 \% \\
(2 / 12)\end{array}$ & $50 \%$ \\
& & $(4 / 12)$ & & $(6 / 12)$ \\
\hline
\end{tabular}

Figures in parentheses indicate number of animals/observations.

Table.2 Mean values of plasma urea, creatinine, protein, cholesterol, calcium and albumin concentrations in normal cyclic and anoestrus buffaloes under various oestrus induction protocols

\begin{tabular}{|c|c|c|c|c|c|c|c|c|}
\hline $\begin{array}{c}\text { Reproducti } \\
\text { ve status }\end{array}$ & Group & $\begin{array}{l}\text { No. of } \\
\text { animals }\end{array}$ & $\begin{array}{c}\text { Urea } \\
\text { mg/dl }\end{array}$ & $\begin{array}{c}\text { Creatinine } \\
\mathrm{mg} / \mathrm{dl}\end{array}$ & $\begin{array}{c}\text { Cholesterol } \\
\text { mg/dl }\end{array}$ & $\begin{array}{c}\text { Calcium } \\
\text { mg/dl }\end{array}$ & $\begin{array}{l}\text { Albumin } \\
\text { g/dl }\end{array}$ & $\begin{array}{l}\text { Protein } \\
\text { g/dl }\end{array}$ \\
\hline \multirow[t]{2}{*}{ Anoestrus } & I & 12 & $\begin{array}{l}27.100 \\
\pm 2.612\end{array}$ & $\begin{array}{r}1.522 \\
\pm 0.071\end{array}$ & $\begin{array}{c}136.500 \\
\pm 7.451\end{array}$ & $\begin{array}{c}8.450 \\
\pm 0.343\end{array}$ & $\begin{array}{c}3.432 \\
\pm 0.112^{\mathrm{a}}\end{array}$ & $\begin{array}{c}7.645 \\
\pm 0.144^{\mathrm{a}}\end{array}$ \\
\hline & II & 12 & $\begin{array}{l}27.367 \\
\pm 3.708\end{array}$ & $\begin{array}{c}1.407 \\
\pm 0.079\end{array}$ & $\begin{array}{l}124.833 \\
\pm 10.091\end{array}$ & $\begin{array}{c}8.333 \\
\pm 0.302\end{array}$ & $\begin{array}{c}3.430 \\
\pm 0.099^{\mathrm{a}}\end{array}$ & $\begin{array}{c}7.555 \\
\pm 0.118^{a}\end{array}$ \\
\hline $\begin{array}{l}\text { Normal } \\
\text { Cyclic }\end{array}$ & Control & 12 & $\begin{array}{l}32.917 \\
\pm 3.262\end{array}$ & $\begin{array}{c}1.652 \\
\pm 0.077\end{array}$ & $\begin{array}{l}129.000 \\
\pm 23.916\end{array}$ & $\begin{array}{c}8.117 \\
\pm 0.224\end{array}$ & $\begin{array}{c}3.898 \\
\pm 0.082^{\mathrm{b}}\end{array}$ & $\begin{array}{c}8.153 \\
\pm 0.212^{b}\end{array}$ \\
\hline
\end{tabular}

Means bearing different superscripts within the column differ significantly $(\mathrm{p}<0.05)$.

Table.3 Mean values of plasma AST, ALT and ALP concentrations in normal cyclic and anoestrus buffaloes under various oestrus induction protocols

\begin{tabular}{|c|c|c|c|c|c|}
\hline $\begin{array}{c}\text { Reproductive } \\
\text { status }\end{array}$ & Group & $\begin{array}{l}\text { No. of } \\
\text { animals }\end{array}$ & AST & ALT & ALP \\
\hline \multirow[t]{2}{*}{ Anoestrus } & I & & $\begin{array}{c}123.283 \\
\pm 5.122\end{array}$ & $\begin{array}{r}55.883 \\
\pm 2.023^{\mathrm{a}}\end{array}$ & $\begin{array}{r}99.333 \\
\pm 17.467\end{array}$ \\
\hline & II & 12 & $\begin{array}{c}121.233 \\
\pm 9.788\end{array}$ & $\begin{array}{c}50.950 \\
\pm 3.004^{\mathrm{a}}\end{array}$ & $\begin{array}{c}98.833 \\
\pm 15.993\end{array}$ \\
\hline $\begin{array}{l}\text { Normal } \\
\text { Cyclic }\end{array}$ & Control & 12 & $\begin{array}{c}126.100 \\
\pm 5.235\end{array}$ & $\begin{array}{c}63.550 \\
\pm 1.507^{b}\end{array}$ & $\begin{array}{c}90.333 \\
\pm 16.737\end{array}$ \\
\hline
\end{tabular}

Means bearing different superscripts within the column differ significantly $(\mathrm{p}<0.05)$.

$\mathrm{ALT}=$ alanine transaminase, $\mathrm{AST}=$ aspartate aminotransferase, $\mathrm{ALP}=$ alkaline phosphatase 
Figure.1 CIDR protocol of oestrus synchronization

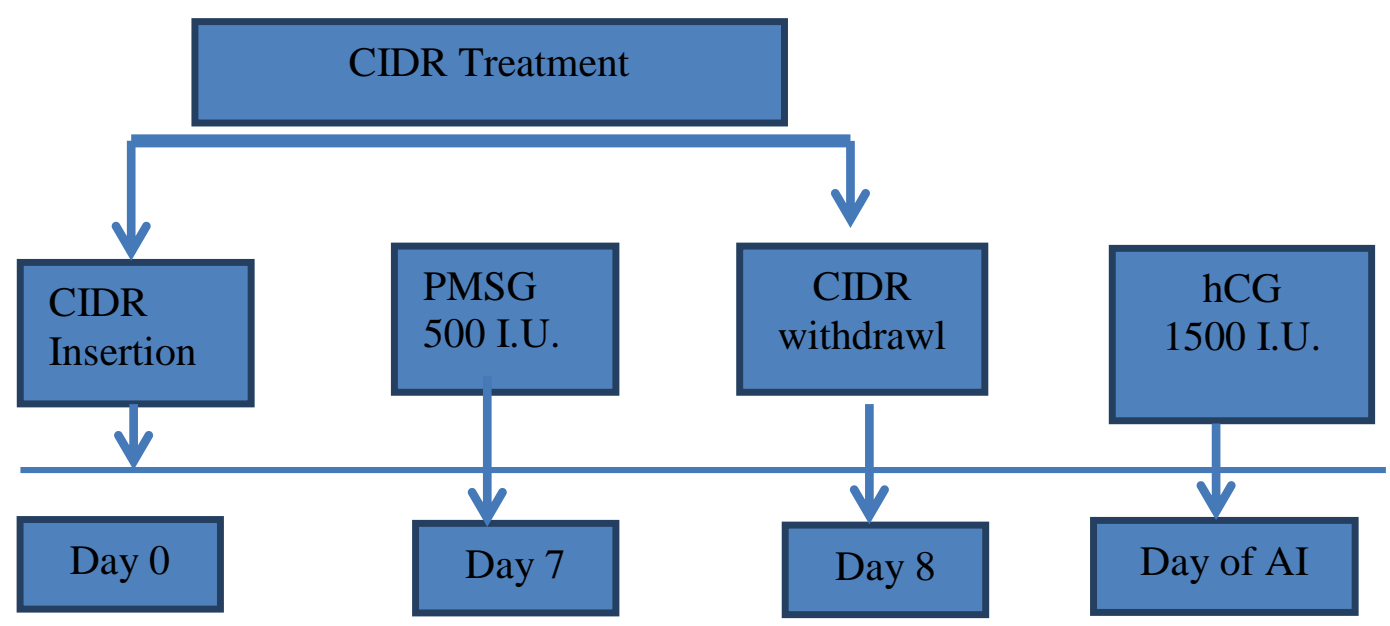

Figure.2 P and E combination protocol of oestrus synchronization

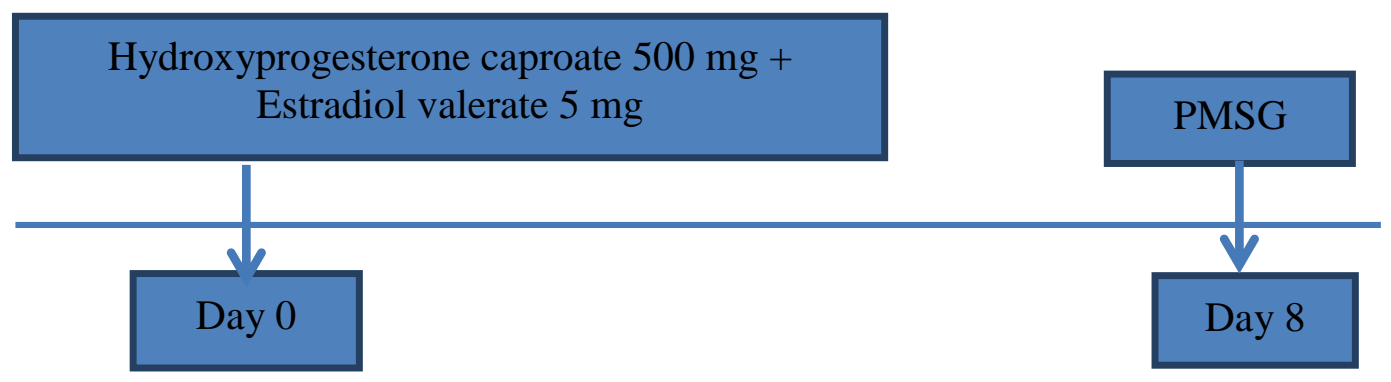

The recurrence of ovarian activity after calving was considerably delayed in buffaloes which calved from February to May as compared to the buffaloes which calved during the rest of the year (Singh and Nanda, 1993). The buffaloes calving from December to June have a mean service period of more than 140 days which was suggestively higher than those buffaloes which are calving inbetween July to November ( $<110$ days), the high service period associated with the initial group was concomitant with extensive silent estruses (Tailor et al.,1997). Madan (1988) also reported poor conception rates in buffaloes during February and August months and number of services for each conception was relatively greater in summer calvers than other animals which are calving in other seasons.
Prevalence of anoestrus in summer conditions has been testified to be stuck between 36-60\% (Singh et al., 1989). The frequency of summer anoestrus in case of wandering and housed rural buffaloes is around 63 and $83 \%$ respectively (Brar and Nanda, 2004). Further, the occurrence of true anoestrus (defined as the absence of large follicles and CL in the ovaries) was around $78 \%$ in July and $14 \%$ in case of November (Singh and Singh, 1985). The summer anoestrus is accompanied with inactive/ smooth ovaries without any follicle or CL (Razdan, 1981; Brar and Nanda, 2004) may be due to lower follicular reserve in case of acyclic buffaloes as compared to the cyclic buffaloes (Danell, 1987). However, other research findings have reported a follicular growth followed by atresia (Pandey and Raizada, 1979; Takkar et al 1983). In addition 
to this, ultrasonographic studies exposed the presence of CL in certain summer anoestrus buffaloes signifying the chance of silent/unobserved oestrus but in preponderance of the cases, a meagre population of follicles trailed by anovulation of preovulatory follicle has been reported (Rohilla, 2005). This retarded follicular growth, anovulation and atresia is possibly endorsed to decreased gonadotropin support during summer season (Aboul- Ela and Barkawi, 1988). The buffaloes are scrawny in expression of oestrus (Jainudden, 1989) and which is additionally aggravated during hot season (De Rensis and Lopez-Gatius, 2007) which are less concentrated with short duration (Jainudeen and Hafez, 2000) and majority display silent oestrus during summer (Chaudhary, 1988). Various seasons have also got contrary effect on manifestation of oestrus indications. Unobserved (silent) oestrus and truncated oestrus duration are collective in swamp buffalo during summer season (Kanai and Shimizu, 1983). The confrontational influence of summer season on manifestation of oestrus signs, service period, and duration may be accredited to rise in ambient temperature and/or photoperiod which desires to be clarified with steering experiments uncoupling photoperiod from high air temperature

Based upon the statistics congregated through the studies on endocrinological characteristics of female buffaloes and outcomes obtained in cattle, diverse hormonal preparations e.g. PGF2 alpha, progestagens, GnRH etc. singlehandedly or in blend with eCG, FSH or PMSG have been used by diverse workers for induction and synchronization oestrus and adjusting ovulation in buffaloes. The effectiveness of different hormonal regime for treatment has been swotted indicating a vivid seasonal variation (De Rensis and LopezGatius, 2007). Progestagens in the form of CIDR, PRID, CRESTAR with or without estradiol valerate/benzoate (at the start of treatment) and $\mathrm{PG}$ or $\mathrm{eCG}$ (at the end of treatment) have been tried to induce oestrus and to synchronize the oestrus cycle in buffaloes with variations in the results irrespective of the season. Still, an appreciable pregnancy rate of $70.5 \%$ was attained in acyclic buffaloes during cumulative day length with CIDR plus PMSG regimen (Presicce et al., 2005). In the similar way, Singh (2003) induced cyclicity in anoestrus buffaloes by means of CIDR during summer season with $83 \%$ induction of cyclicity and $80 \%$ of the detected animals in oestrus conceived following treatment. However, during summer, treatment with progesterone/norgestomet induced oestrus only in 62-66\% anoestrus buffaloes with 40$50 \%$ conception of the detected animals (Dahiya et al. 2003). These studies indicate enhanced results with CIDR as compare to progestagens and PRID. Further, in anoestrous buffaloes during progesteronebased oestrus synchronization protocol, administration of eCG equine chorionic gonadotropin (eCG) at the time of progesterone withdrawal, improved the ovulation rate in buffaloes (Rao et al. 1985; Singh et al. 1988). However, acyclic buffaloes respond poorly to the Ovsynch protocol yielding poor conception/pregnancy rates, compared to cyclic buffalo cows (DeRensis et al. 2005 and Ali and Fahmy, 2007). During summer, high degree of ovulation was achieved with Ovsynch protocol in cyclic buffalo (80-100\%) (Ali and Fahmy, 2007; Roy and Prakash, 2007) as compare to acyclic but with poor conception rate in acyclic buffaloes owing to asynchronous ovulation (Ali and Fahmy, 2007). This poor pregnancy rates in non-cyclic/anoestrous buffaloes following Ovsynch protocol during summer was improved by adding exogenous progesterone with an intra-vaginal progesterone device (De-Rensis et al., 2005) and addition of norprolac (anti-prolactin drug) 
to the Ovsynch protocol (Roy and Prakash, 2007). Administration of PG adopting same protocol at the time of AI in cyclic buffaloes during breeding season by enhancing progesterone profiles also increased conception rate (Presicce et al., 2005). However, the efficacy of presynch ovsynch and ovsynch protocol was found to be similar with regard to ovulation (85-90\%) and conception rate $35-45 \%$ (Oropeza et al., 2010).

The oestrus induction results using CIDR protocol are in relation with the oestrus induction findings in case of cow (El-Shahat and Badr, 2011). Higher pregnancy rate in CIDR group might be due to hCG as well as PMSG along with CIDR. The hCG administration at the time of insemination could result in the fertilization, synchronization of ovulation and proceedings obligatory for the successful conservation of pregnancy (Breuel et al., 1989). eCG arouses the progress of dominant follicle that subsequently increases ovulation rate (Sa Filho et al., 2010), exclusively in cows in postpartum anoestrus and/or in low BCS (Bo et al., 2007). Intrusion of eCG to the progesterone schedule expressively upgraded all reproductive consequences in anoestrous dairy cows (Bryan et al., 2013). The use of eCG in combination with progesterone devices has also been established to escalate pregnancy rates in Bos taurus and Bos indicus herds with extraordinary prevalence of postpartum anoestrus (Baruselli et al., 2004 and Bo et al., 2007). However, administration of eCG at the phase of CIDR removal in an estradiol-based organisation treatment did not rise the ovulatory follicular size and pregnancy rates were only considerably upgraded in cows with a BCS $<2.75$ in lactating cattle (Small et al., 2009). Slight or no substantial improvement in pregnancy rates using Ovsynch has been described in lactating dairy cows (Rabiee et al., 2005). The
Ovsynch protocol performs to persuade ovulation in a high proportion of anoestrus dairy cows, but certain of these cows have an ensuing short luteal phase (Gumen et al., 2003 and McDougall, 2010) resulting in worse conception rates than in cycling cows. Klindworth et al. (2001) also conveyed an encouraging effect of Ovsynch in acyclic cows and witnessed that nine out of eleven cows responded with the resumption of ovarian activity and other two cows were pregnant after first insemination. Even though Ovsynch may encourage ovulation in noncycling cows, there is still possibility that there may be a decline in conception rates in these cows.

In conclusion, the present study clearly indicates that the induction of cyclicity, oestrus synchronization, and improvement in conception is possible with the use of different hormone protocols, viz., CIDR as well as $\mathrm{P}$ and $\mathrm{E}$ combination in anoestrous Murrah buffaloes. Although oestrus induction was $100 \%$ with both the hormone protocols, their relative efficacy varied. CIDR protocol provided excellent fertility with conception rate up to $83.33 \%$ whereas $\mathrm{P}$ and $\mathrm{E}$ protocol yielded relatively poor conception rate of around $50 \%$, which was attributed to reduced dose of GnRH and high potency of estradiol benzoate used. Thus, to maintain a high degree of breeding efficiency among lactating Murrah buffaloes of the Trans Gangetic plain regions like India, use of advanced reproductive management strategies like oestrus induction/synchronization appears to be a valuable tool.

From the results, it can be inferred that higher conception rate was recorded by the administration of progesterone based CIDR protocol as compared to the $\mathrm{P}$ and $\mathrm{E}$ protocol in anoestrus buffaloes under field conditions, hence it can be used by the practicing veterinarians in anoestrus rural Murrah 
buffaloes to improve their reproductive efficiency and thereby the economy of farmers.

\section{References}

Aboul-Ela, M. B \& Barkawi, A. H. (1988). Pulsatile secretion of LH in cycling buffalo heifers as affected by season and stage of oestrous cycle. (Paper presented at the 11th International Congress on Animal Reproduction and Artificial Insemination, Dublin, Ireland)

Ali, A \& Fahmy, S. (2007). Ovarian dynamics and milk progesterone concentrations in cycling and non-cycling buffalo-cows (Bubalus bubalis) during Ovsynch program. Theriogenology, 68, 23-28

Balakrishnan, M., Ramesha, K.P. \& Chinnaiya, G.P. (1997). Effect of post-partum body condition loss on performance in crossbred cows an assessment through body condition scoring. Indian Journal of Dairy Science, 50, 393-397

Barile, V.L. (2005). Improving reproductive efficiency in female buffaloes. Livestock Production Science, 92, 83-194.

Baruselli, P. S. (2001). Control of follicular development applied to reproduction biotechnologies in buffalo. (Paper presented at the I Congresso Nazionale sull'Allevamento del Bufalo, Italy)

Baruselli, P.S., Reis, E.L., Marques, M.O., Nasser, L.F. and Bo, G.A. (2004). The use of treatments to improve reproductive performance of anoestrus beef cattle in tropical climates. Animal Reproduction Science. 82, 479-486.

Bo, G.A., Cutaia, L., Peres, L.C., Pincinato, D., Marana, D. and Baruselli, P.S. (2007). Technologies for Fixed-Time Artificial Insemination and Their Influence on Reproductive Performance of Bos indicus Cattle. Paper presented at the Reproduction in Domestic Ruminants VI. Juengel JL, Murray JF, Smith MF (eds.). Nottingham, UK: Nottingham University Press.

Brar, P. S., Nanda, A. S. 2004. Impact of conventional managemental practices on reproductive performance of rural buffaloes. Indian J Anim Reprod, 25, pp. 94-96.

Breuel, K.F., Spitzer, J.C. and Henricks, D.M. (1989). Systemic progesterone concentration following human chorionic gonadotropin administration in various times during the oestrous cycle in beef heifers. J. Anim. Sci. 67: 1564-1572

Bryan, M.A., Bó, G., Mapletoft, R.J. and Emslie, F.R. (2013). The use of equine chorionic gonadotropin in the treatment of anoestrous dairy cows in gonadotropin-releasing hormone/ progesterone protocols of 6 or 7 days. J. Dairy Sci. 96: 122131.

Chaudhary, R. A. 1988. Recent advances in female reproduction. In: Proceedings of Second world Buffalo Congress, December, 1988, Delhi, India, Vol. II, Part I, pp. 225228.

Dahiya, V., Lohan, J. S., Saini, M. S., Kaker, M. L., Malik, R. K. 2003. Ultrasonographic assessment of ovarian changes in anoestrous buffaloes treated with norgestomet. Indian J Anim Sci, 73, pp. 1033-1036.

Danell, B. 1987. Oestrus behaviour, ovarian morphology and cyclical variation in the follicular system and endocrine pattern in Water Buffalo heifers. PhD Dissertation, Swedish University of Agricultural Science, Uppsala.

De Rensis, F, Lopez-Gatius, F. 2007. Protocols for synchronizing oestrus and ovulation in buffalo (Bubalus bubalis): a review. Theriogenology, 67, pp. 209-216.

De Rensis, F., Ronchi, G., Guarneri, P., Nguyen, B. X., Presicce, G. A., Huszenicza, G. 2005. Conception rate after fixed time insemination following Ovsynch protocol with and without progesterone supplementation in cyclic and non-cyclic Mediterranean Italian buffaloes (Bubalus bubalis). Theriogenology, 63, pp. 18241831.

El-Shahat, K.H. and Badr, A. (2011). Comparative study on efficacy of different medicaments on postpartum anoestrus in dairy cows. J. Appl. Biol. Sci. 5: 59-63.

FAOSTAT. 2007. http://faostat.fao.org

Gumen A, Guenther JN, Wiltbank MC. (2003). 
Follicular size and response to Ovsynch versus detection of oestrus in anovular and ovular lactating dairy cows. J. Dairy Sci. 86: 3184-3194.

Jainudeen, M. R. 1989. Reproduction in the buffalo. In: Noakes DE, Parkinson TJ, England GCW (eds), Arthur's Veterinary Reproduction and Obstetrics, 8th edn. Saunders Harcourt, India, pp. 789-800.

Jainudeen, M. R., Hafez, E. S. E. 2000. Reproductive cycles in cattle and buffaloes. In: Hafez ESE, Hafez B (eds), Reproduction in Farm Animals, 7th edition. Lea and Febiger, Baltimore, Maryland, USA, pp. 297- 314.

Kanai, Y., Shimizu, H. 1983. Characteristics of the oestrous cycle in swamp buffalos under temperate conditions, Theriogenology, 19, pp. 593-602

Klindworth, H.P., Hoedemaker, M. Burfeindt, D. and Heilkenbrinker, T. (2001). Synchronization of ovulation (Ovsynch) in high producing dairy cattle herds. I. Fertility parameters, body condition score and plasma progesterone concentration. Dtsch Tierarztl Wochenschr. 108: 1-9.

Madan, M. L. 1988. Status of reproduction in female buffalo. In: Buffalo Production and Health: a compendium of latest research information based on Indian studies, ICAR Publication, New Delhi, India, pp. 89-100.

Madan, M. L. 1990. Factors limiting superovulation responses in embryo transfer programs among buffaloes. Theriogenology, 33, pp. 280.

McDougall, S. (2010). Effects of treatment of anoestrous dairy cows with gonadotropinreleasing hormone, prostaglandin and progesterone. J. Dairy Sci. 93: 1944-1959.

Oropeza, A. J., Rojas, A. F., Velazquez, A. M., Muro, J. D., Márquez, Y. C., Vilanova, L. T. 2010. Efficiency of two timed artificial insemination protocols in Murrah buffaloes managed under a semi-intensive system in the tropics. Trop. Anim. Health Prod. 42, pp. 1149-1154.

Pandey, M. D., Raizada, B. C. 1979. Overcoming summer sterility in buffalo bulls and cows. In: Buffalo Reproduction and Artificial Insemination. FAO, Rome, FAO Animal Production and Health Paper No. 13, pp.
235-246.

Presicce, G. A., Senatore, E. M., De Santis, G., Bella, A. 2005. Follicle turnover and pregnancy rates following oestrus synchronization protocols in Mediterranean Italian buffaloes (Bubalus bubalis). Reprod Domest Anim, 40, pp. 443-447

Rabiee, A.R., Lean, I.J. and Stevenson, M.A. (2005). Efficacy of Ovsynch program on reproductive performance in dairy cattle: a meta-analysis. J. Dairy Sci. 88: 2754-2770.

Rao, A. V. N, Sreemannarayana, O., Rao, K. P. 1985. Oestrous response and fertility in post-partum anoestrus buffaloes treated with progestagen, pregnant mares' serum gonadotropin and prostaglandin during the low breeding season. Anim Reprod Sci, 8, pp. 129-135.

Razdan, M. N., Kaker, M. L., Galhotra, M. M. 1981. Serum luteinizing hormone levels of non-cycling buffaloes (Bubalus bubalis). Indian J Anim Sci, 51, pp. 286-288.

Ribeiro, H. F. L., Vale, W. G., Andrade, V. J., Marques, Jr. A. P. 2003. Environmental effect on the ovarian postpartum activity in the buffaloes raised in low Amazon region, Brazil. Buff J, 19, pp. 311-321.

Rohilla, N., Singh, U., Sharma, R. K., Singh, I. 2005. Ultrasonic ovarian status in summer anoestrus postpartum Murrah buffaloes. Indian J Anim Reprod, 26, pp. 95-98

Roy, K.S., Prakash, B.S. 2007. Seasonal variation and circadian rhythmicity of the prolactin profile during the summer months in repeat-breeding Murrah buffalo heifers. Reprod Fertil Dev, 19, pp. 596-605

Sá Filho, M.F., Ayres, H., Ferreira, R.M., Marques, M.O., Reis, E.L., Silva, R.C., Rodrigues, C.A., Madureira, E.H., Bó, G.A. and Baruselli, P.S. (2010). Equine chorionic gonadotropin and gonadotropin-releasing hormone enhance fertility in a norgestometbased, timed artificial insemination protocol in suckled Nellore (Bos indicus) cows. Theriogenology. 73: 651-658.

Shah, S. N. H. 1988. Comparative studies of seasonal influence on breeding behaviour and conception rate of dairy buffalo and zebu cattle. In: Proc. 11th Int. Congress on Animal Reproduction and Artificial Insemination vol. 3, pp. 538. 
Singh, C. 2003. Response of anoestrus rural buffaloes (Bubalus bubalis) to intravaginal progesterone implant and PGF2a injection in summer. J Vet Sci, 4, pp.137-141.

Singh, G., Singh, G. B. 1985. Effect of month of calving on postpartum oestrous interval and service period in Murrah buffaloes, Proceedings of the First World Buffalo Congress, vol. IV Cairo, Egypt, pp. 960963.

Singh, G., Singh, G. B., Dhaliwal, G. S. 1989. Studies on reproductive status of rural buffaloes in summer. Indian $\mathbf{J}$ Anim Reprod, 10, pp. 151-153.

Singh, J., Nanda, A. S., Adams, G. P. 2000. The reproductive pattern and efficiency of female buffaloes. Anim Reprod Sci, 60-61, pp. 593-604.

Singh, J.K., Sharma, R.K., Singh, I. and Singh, S. (2004). Ovarian follicular dynamics during oestrus induction and subsequent fertility of true anoestrus per pubertal Murrah heifers receiving Ovsynch and Ovsynch plus treatments. Proc. National Seminar on economic feeding and rearing of buffaloes under different agro climatic regimens, Jhansi

Singh, M., Chaudhary, K. C., Takkar, O. P. 1988. Increasing the reproductive performance of buffaloes. In: Proceedings of Second World Buffalo Congress, Vol. 2, pp. 271-282.
Singh, R., Nanda, A. S. 1993. Environmental variables governing seasonality in buffalo breeding. J Anim Sci, 71, pp. 119.

Small, J.A., Colazo, M.G., Kastelic, J.P. and Mapletoft, R.J. (2009). Effects of progesterone pre-synchronization and eCG on pregnancy rates to GnRH-based, timedAI in beef cattle. Theriogenol. 71: 698-706.

Snedecor, G.W. and Cochran, W.G. (1994) Statistical Methods. 14th ed. Oxford and IBH Publishing House, New Delhi, India.

Tailor, S. P., Banerjee, A. K., Singh, B., Pathodiya, O. P. 1997. Factors affecting reproductive performance in Surti buffaloes. Indian J Dairy Sci, 50, pp. 407409.

Tailor, S. P., Jain, L. S., Gupta, H. K., Bhatia, J. S. 1990. Oestrus and conception rates in buffaloes under village conditions. Indian $\mathrm{J}$ Anim Sci, 60, pp. 1020-1021.

Takkar, O. P., Singh, M., Verman, P. N. 1983. Progesterone levels vis a vis anoestrum in buffaloes concurrent with profile during stages of oestrus cycle. Indian J Dairy Sci, 36, pp.125-128.

Zicarelli. L. 1994. Management under different environmental conditions. Buff J (Suppl.), 2, pp. 17-38.

\section{How to cite this article:}

Meenakshi Virmani, R.K. Malik, Kennady Vijayalakshmy, Pardeep Singh and Chhikara, S.K. 2018. Management of Anoestrus Murrah Buffaloes Using Two Different Hormonal Approaches. Int.J.Curr.Microbiol.App.Sci. 7(01): 3427-3437. doi: https://doi.org/10.20546/ijcmas.2018.701.404 